\title{
ESTUDO DO AGREGADO MIÚDO: CARACTERIZAÇÃO E EFEITOS DA GRANULOMETRIA NA PRODUÇÃO DO CONCRETO
}

\author{
Nicolas Montanari ${ }^{1}$ \\ Erika Peterson Gonçalves ${ }^{2}$
}

Resumo: A norma define a areia como sendo de origem natural ou resultante do britamento de rochas estáveis, ou mistura de ambas, cujos grãos passam pela peneira ABNT 4,8 $\mathrm{mm}$ e ficam retidos na peneira ABNT 0,075 mm. Esta areia possui diferentes propriedades como composição granulométrica, módulo de finura, curva granulométrica e coeficiente de uniformidade, estas propriedades foram estudadas através de ensaios normatizados realizados em três amostras distintas, além de uma elaborada teoricamente que estabeleceu uma variação granulométrica ótima, além de um valor de coeficiente de uniformidade máximo para o agregado miúdo. Este estudo constatou que o material disponível na faculdade apresenta propriedades superiores comparado ao material comercializado regionalmente, e que o processo de moagem reduziu o diâmetro dos grãos, porém é ineficaz, causando por deixar uma fração uma fração de diâmetros sem material e reduzir o coeficiente de uniformidade da amostra, o qual se constatou importante. Palavras-chave: Método ABCP; Concreto; Granulometria; Agregado miúdo; Coeficiente uniformidade.

\footnotetext{
${ }^{1}$ Engenharia Civil/Universidade do Vale do Paraíba - UNIVAP, Brasil. E-mail: nicolas.montanari@yahoo.com.

2 Engenharia Civil/Universidade do Vale do Paraíba - UNIVAP, Brasil. E-mail: erika@univap.br.
} 